\title{
Interleukin-5 mediates peritoneal eosinophilia induced by the F1 cell wall fraction of Histoplasma capsulatum
}

A. Sá-Nunes,

A.I. Medeiros and

L.H. Faccioli
Departamento de Análises Clínicas, Toxicológicas e Bromatológicas, Faculdade de Ciências Farmacêuticas de Ribeirão Preto, Universidade de São Paulo, Ribeirão Preto, SP, Brasil

\section{Correspondence}

L.H. Faccioli

Departamento de Análises Clínicas,

Toxicológicas e Bromatológicas FCFRP, USP

Av. do Café, $s / n$

14040-903 Ribeirão Preto, SP

Brasil

Fax: + 55-16-633-1936

E-mail: faccioli@fcfrp.usp.br

Presented at the XVIII Annual Meeting of the Federação de Sociedades de Biologia Experimental, Curitiba, PR, Brazil, August 27-30, 2003.

Research supported by FAPESP (No. 95/9691-6), CNPq and FAEPA.

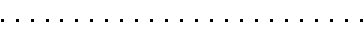

Received May 8, 2003 Accepted November 13, 2003

\begin{abstract}
An alkali-insoluble fraction 1 (F1), which contains mainly ß-glucan isolated from the cell wall of Histoplasma capsulatum, induces eosinophil recruitment into the peritoneal cavity of mice. The present study was carried out to determine the participation of interleukin-5 (IL-5) in this process. Inbred C57BL/6 male mice weighing 15-20 g were treated ip with $100 \mu \mathrm{g}$ of anti-IL-5 monoclonal antibody (TRFK-5, N =7) or an isotype-matched antibody $(\mathrm{N}=7)$, followed by $300 \mu \mathrm{g} \mathrm{F} 1$ in $1 \mathrm{ml}$ PBS ip $24 \mathrm{~h}$ later. Controls $(\mathrm{N}=5)$ received only $1 \mathrm{ml} \mathrm{PBS}$. Two days later, cells from the peritoneal cavity were harvested by injection of $3 \mathrm{ml} \mathrm{PBS}$ and total cell counts were determined using diluting fluid in a Neubauer chamber. Differential counts were performed using Rosenfeld-stained cytospin preparations. The F1 injection induced significant $(\mathrm{P}<0.01)$ leukocyte recruitment into the peritoneal cavity $\left(8.4 \times 10^{6}\right.$ cells $\left./ \mathrm{ml}\right)$ when compared with PBS alone $\left(5.5 \times 10^{6}\right.$ cells/ $\mathrm{ml})$. Moreover, F1 selectively $(\mathrm{P}<0.01)$ induced eosinophil recruitment $\left(1 \times 10^{6}\right.$ cells $\left./ \mathrm{ml}\right)$ when compared to the control group $\left(0.07 \times 10^{6}\right.$ cells $/ \mathrm{ml})$. Treatment with TRFK-5 significantly $(\mathrm{P}<0.01)$ inhibited eosinophil recruitment $\left(0.18 \times 10^{6}\right.$ cells $\left./ \mathrm{ml}\right)$ by $\mathrm{F} 1$ without affecting recruitment of mononuclear cells or neutrophils. We conclude that the F1 fraction of the cell wall of $H$. capsulatum induces peritoneal eosinophilia by an IL-5-dependent mechanism. Depletion of this cytokine does not have effect on the recruitment of other cell types induced by F1.
\end{abstract}

The eosinophil granulocyte, although probably first observed by Warton Jones in 1846 in unstained preparations of peripheral blood, was so named by Paul Erlich in 1879 because of the intense staining of its granules with the acidic dye eosin (1). Eosinophils have been the subject of extensive investigation since then and their occurrence is observed mainly in parasite infections and in the late phase of immediate hypersensitivity reactions (2,3). For several years we have investigated the mechanisms involved in eosinophil recruitment. We have developed and studied a system to measure the accumulation of radiolabeled ${ }^{111}$ In-eosinophils in guinea pig skin in vivo (4). Using this same method, we have demonstrated the eosinophil chemoattractant activity of interleukin8 (IL-8) (5) and eosinophil accumulation induced by LPS (6). More recently we have
Key words

- Eosinophils

- Histoplasma capsulatum

- Inflammation

- Inkin-5

Anti-IL-5 monoclonal antibody 
investigated the factors involved in eosinophil migration in different experimental models of eosinophilia. Using a murine model of toxocariasis, a nematode infection, we demonstrated the role of IL-5 in driving eosinophils from bone marrow to blood and tissues and in modulating IL-8 production in eosinophilic inflammation $(7,8)$. In addition, we demonstrated that leukotrienes play a role in the leukocyte recruitment to the peritoneal cavity induced by the alkali-insoluble fraction 1 (F1), which contains mainly B-glucan, from the cell wall of Histoplasma capsulatum, a dimorphic pathogenic fungus (9). In the present study we investigated the participation of IL-5 in eosinophil recruitment to the peritoneal cavity induced by the F1 cell wall fraction of $H$. capsulatum.

All experiments were approved and conducted in accordance with the guidelines of the Animal Care Committee of the University.

Inbred C57BL/6 male mice weighing 15 $20 \mathrm{~g}$ were purchased from the animal house of the Faculdade de Ciências Farmacêuticas de Ribeirão Preto, Universidade de São Paulo, Ribeirão Preto, SP, Brasil, and were maintained under standard laboratory conditions. The F1 polysaccharide of $H$. capsulatum was prepared as described (10). Briefly, yeast forms of the fungus were cultured at $37^{\circ} \mathrm{C}$ in BHI-agar medium (Difco Laboratories, Sparks, MD, USA) and supplemented with $5 \%$ sheep blood for 15 days. Yeasts were harvested, formalin-killed and washed several times with distilled water. The cell walls of the dead yeast were disrupted by ultrasonic vibration and washed three times with distilled water by centrifugation at $5000 \mathrm{~g}$ for $5 \mathrm{~min}$. Lipids were extracted by repeated soaking of the walls in chloroform/methanol $(2: 1, \mathrm{v} / \mathrm{v})$ at room temperature for $2 \mathrm{~h}$ with shaking. The extracts were separated by centrifugation at $5000 \mathrm{~g}$ for $5 \mathrm{~min}$ and the insoluble residue was extracted three more times as described above. The resulting insoluble cell wall residue was suspended in 1
$\mathrm{N} \mathrm{NaOH}$ and gently stirred at room temperature for $1 \mathrm{~h}$. After centrifugation at $5000 \mathrm{~g}$ for $10 \mathrm{~min}$, the supernatants were collected and the procedure was repeated four times. The alkali-insoluble sediment was washed with ethanol followed by acetone and diethyl ether. After drying, the resulting white powder was designated as F1 from the dead yeast form of $H$. capsulatum.

In order to induce leukocyte recruitment into the peritoneal cavity, $300 \mu \mathrm{g} \mathrm{F} 1$ was suspended in $1 \mathrm{ml}$ PBS and was injected $i p$ in mice $(\mathrm{N}=14)$. Control mice received only 1 $\mathrm{ml}$ PBS $(\mathrm{N}=5)$. This protocol induces timedependent leukocyte migration with characteristic kinetics among neutrophils, eosinophils, and mononuclear cells (9). Twentyfour hours prior to F1 injection, one group of mice $(\mathrm{N}=7)$ received an ip injection of 100 $\mu \mathrm{g}$ TRFK-5, an anti-IL-5 monoclonal antibody $(\mathrm{mAb})$, and the other group $(\mathrm{N}=7)$ received an isotype-matched $\mathrm{mAb}$. This treatment was given in order to determine the participation of IL-5 in eosinophil recruitment. Forty-eight hours after F1 injection the animals were sacrificed by excess anesthesia because $48 \mathrm{~h}$ corresponds to the peak of eosinophil recruitment in this model (9). Cells from the peritoneal cavities were harvested by injection of $3 \mathrm{ml}$ PBS containing 5 $\mathrm{U} / \mathrm{ml}$ heparin. The abdomens were gently massaged and a blood-free cell suspension was carefully withdrawn with a syringe. Abdominal washings were placed in plastic tubes and total cell counts were performed immediately in a Neubauer chamber. Differential counts were obtained using Rosenfeldstained cytospin preparations (7). Statistical differences were analyzed by the Student $t$ test. Two-way ANOVA was used to calculate the differences of significance among the groups. A P $<0.05$ value was considered to be statistically significant.

The response of mice to ip administration of $\mathrm{F} 1$ after $48 \mathrm{~h}$ was the recruitment of $8.4 \pm 1.25 \times 10^{6}$ cells $/ \mathrm{ml}$ compared to $5.5 \pm$ $0.31 \times 10^{6}$ cells $/ \mathrm{ml}$ obtained with PBS $(\mathrm{P}<$ 
$0.01)$. The numbers of neutrophils, eosinophils, and mononuclear cells after F1 injection were also determined and the effect of TRFK-5 on the recruitment of these cells is shown in Figure 1. No differences in mononuclear cell counts were observed between control mice and mice injected with F1, who were treated with either TRFK-5 or with the isotype antibody (Figure 1C). However, F1 induced significantly greater $(\mathrm{P}<0.01)$ neutrophil recruitment $\left(4.4 \times 10^{5}\right.$ cells $\left./ \mathrm{ml}\right)$ when compared to PBS $\left(0.6 \times 10^{5}\right.$ cells $\left./ \mathrm{ml}\right)$. Treatment of mice with TRFK-5 increased neutrophil recruitment induced by F1 (Figure 1B). In addition, eosinophil recruitment by F1 $\left(1 \times 10^{6}\right.$ cells $\left./ \mathrm{ml}\right)$ was 14 -fold higher $(\mathrm{P}<$ 0.01) compared to the PBS control group $\left(0.07 \times 10^{6}\right.$ cells $\left./ \mathrm{ml}\right)$. Treatment with TRFK5 significantly $(\mathrm{P}<0.01)$ inhibited eosinophil recruitment into the peritoneal cavity by more than $80 \%$ (Figure $1 \mathrm{~A}$ ).

Both granulocyte-macrophage colonystimulation factor and IL-3 stimulate the recruitment of eosinophils as well as other leukocytes, whereas IL-5 specifically supports the terminal differentiation and proliferation of eosinophil precursors as well as the eosinophil activation effect (11-13). Several chemoattractants are involved in both in vitro and in vivo eosinophil migration. Many investigators have demonstrated a direct correlation between eosinophilia and IL-5 in human helminth infection and in experimental animal models. It has also been demonstrated that anti-IL-5 mAb treatment inhibits eosinophilia in mice infected with Toxocara canis, Nippostrongylus brasiliensis and Schistosoma mansoni (14-16). In addition, IL-5 plays an important role in mobilizing eosinophils from bone marrow to peripheral blood and in priming eosinophils to respond easily to other chemotactic stimuli such as chemokines and lipid mediators $(7,17)$. When a low dose of IL-5 is administered intravenously, it rapidly and dramatically enhances the eosinophil accumulation induced by intradermally injected eotaxin and leukotriene
$\mathrm{B}_{4}(17)$, suggesting a link between chemoattractant factors and IL-5. It has been demonstrated that the chemotactic activity of eosinophils in bronchoalveolar lavage fluid obtained from rats infected with $T$. canis was significantly reduced after treatment with either a specific leukotriene $\mathrm{B}_{4}$ receptor antagonist (ONO-4057), a platelet aggregating factor receptor antagonist (TCV-309), and an anti-IL-5 mAb (TB13) (18). This suggests that these three factors contribute to the accumulation of eosinophils in the lungs of rats infected with $T$. canis. More recently, it was shown that antigen-induced eosinophilia in the lung is indirectly dependent on cysteinyl leukotrienes through IL-5 production in a model of late asthmatic response (19). We
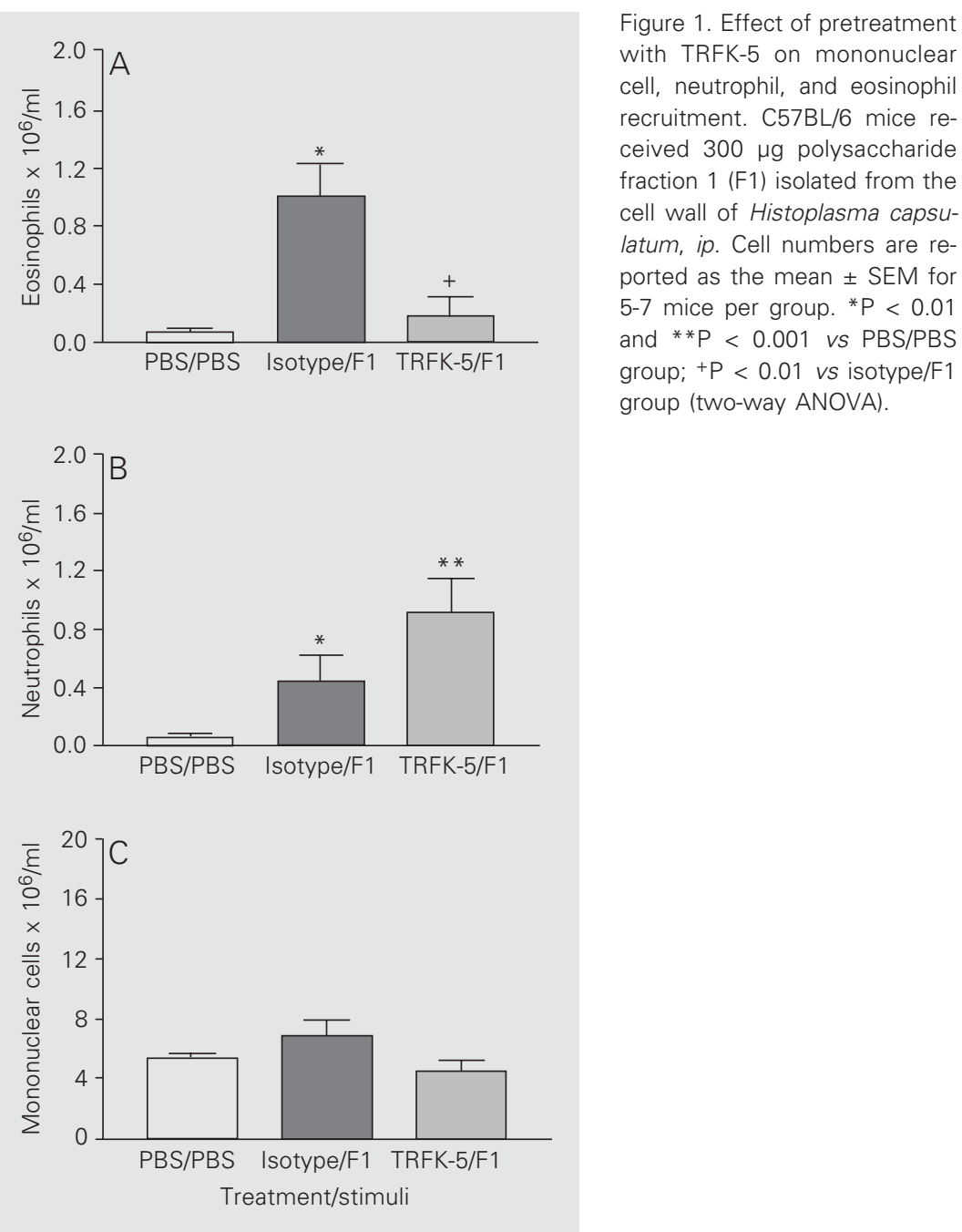
demonstrated that leukotrienes are involved in leukocyte recruitment induced by $\mathrm{F} 1$ of $H$. capsulatum. Treatment of mice with the MK886 compound, an inhibitor of leukotriene synthesis, partially blocked neutrophil, eosinophil, and mononuclear cell recruitment (9).

Interestingly, there was an increase in neutrophil recruitment to the peritoneal cavity induced by $\mathrm{F} 1$ in the group treated with TRFK-5. We have demonstrated that TRFK5 suppressed eosinophilia and increased IL8 levels in guinea pigs infected with $T$. canis, a nematode parasite (8). Probably the same phenomena occurred in F1 TRFK-5-treated mice. The decrease in IL- 5 by TRFK- 5 treatment should up-regulate the $\mathrm{KC}$ chemokine (murine IL-8) levels, and F1 should recruit more neutrophils to the peritoneal cavity, since this molecule is chemotactic for neutrophils (20).

Finally, in the present study we demonstrated that F1-induced eosinophil recruitment, but not the recruitment of other cell types, is IL-5-dependent within a specific time window, i.e., $48 \mathrm{~h}$ after $\mathrm{F} 1$ injection. We suggest that the eosinophil recruitment induced by ip injection of F1 is mediated by an interaction between at least two eosinophilic mediators, leukotrienes and IL-5.

\section{References}

1. Gleich GJ \& Adolphson CR (1986). The eosinophilic leukocyte: structure and function. Advances in Immunology, 39: 177-253.

2. Finkelman FD, Pearce EJ, Urban Jr JF \& Sher A (1991). Regulation and biological function of helminth-induced cytokine responses. Immunology Today, 12: A62-A66.

3. Calhoun WJ, Sedgwick J \& Busse WW (1991). The role of eosinophils in the pathophysiology of asthma. Annals of the New York Academy of Sciences, 629: 62-72.

4. Faccioli LH, Nourshargh S, Mogbel R, Williams FM, Sehmi R, Kay $A B$ \& Williams TJ (1991). The accumulation of ${ }^{111}$ In-eosinophils induced by inflammatory mediators, in vivo. Immunology, 73: 222227.

5. Collins PD, Weg VB, Faccioli LH, Watson ML, Mogbel R \& Williams TJ (1993). Eosinophil accumulation induced by human interleukin-8 in the guinea-pig in vivo. Immunology, 79: 312-318.

6. Weg VB, Walsh DT, Faccioli LH, Williams TJ, Feldmann M \& Nourshargh S (1995). LPS-induced ${ }^{111}$ In-eosinophil accumulation in guinea-pig skin: evidence for a role for TNF-alpha. Immunology, 84: 36-40.

7. Faccioli LH, Mokwa VF, Silva CL, Rocha GM, Araújo JI, Nahori MA \& Vargaftig BB (1996). IL-5 drives eosinophils from bone marrow to blood and tissues in a guinea-pig model of visceral larva migrans syndrome. Mediators of Inflammation, 5: 24-31.

8. Faccioli LH, Medeiros Al, Malheiro A, Pietro RC, Januario A \& Vargaftig BB (1998). Interleukin-5 modulates interleukin-8 secretion in eosinophilic inflammation. Mediators of Inflammation, 7: 41-47.

9. Medeiros Al, Silva CL, Malheiro A, Maffei CM \& Faccioli LH (1999). Leukotrienes are involved in leukocyte recruitment induced by live Histoplasma capsulatum or by the beta-glucan present in their cell wall. British Journal of Pharmacology, 128: 1529-1537.

10. Carareto-Alves LM, Figueiredo F, Brandão Filho SL, Tincani I \& Silva $C L$ (1987). The role of fractions from Paracoccidioides brasiliensis in the genesis of inflammatory response. Mycopathologia, 97: 3-7.

11. Sanderson CJ, Warren DG \& Strath M (1985). Identification of a lymphokine that stimulates eosinophil differentiation in vitro. Its relationship to interleukin 3 , and functional properties of eosinophils produced in cultures. Journal of Experimental Medicine, 162: 60-74.

12. Yamaguchi $Y$, Hayashi $Y$, Sugama $Y$, Miura $Y$, Kasahara T, Kitamura S, Torisu M, Mita S, Tominaga A \& Takatsu K (1988). Highly purified murine interleukin 5 (IL-5) stimulates eosinophil function and prolongs in vitro survival. IL-5 as an eosinophil chemotactic factor. Journal of Experimental Medicine, 167: 1737-1742.

13. Coeffier E, Joseph D \& Vargaftig BB (1991). Activation of guinea pig eosinophils by human recombinant IL-5. Selective priming to platelet-activating factor-acether and interference of its antagonists. Journal of Immunology, 147: 2595-2602.

14. Parsons JC, Coffman RL \& Grieve RB (1993). Antibody to interleukin-5 prevents blood and tissue eosinophilia but not liver trapping in murine larval toxocariasis. Parasite Immunology, 15: 501-508.

15. Coffman RL, Seymour BWP, Judak S, Jackson J \& Rennick D (1989). Antibody to interleukin-5 inhibits helminth-induced eosinophilia in mice. Science, 245: 308-310.

16. Sher A, Coffman RL, Hieny S \& Cheever AW (1990). Ablation of eosinophil and IgE responses with anti-IL-5 or anti-IL-4 antibodies fails to affect immunity against Schistosoma mansoni in the mouse. Journal of Immunology, 145: 3911-3916.

17. Collins PD, Marleau S, Griffiths-Johnson DA, Jose PJ \& Williams TJ (1995). Cooperation between interleukin-5 and the chemokine eotaxin to induce eosinophil accumulation in vivo. Journal of Experimental Medicine, 182: 1169-1174.

18. Okada K, Fujimoto K, Kubo K, Sekiguchi M \& Sugane K (1996). Eosinophil chemotactic activity in bronchoalveolar lavage fluid obtained from Toxocara canis-infected rats. Clinical Immunology and Immunopathology, 78: 256-262.

19. Nabe T, Yamashita K, Miura M, Kawai T \& Kohno S (2002). Cysteinyl leukotriene-dependent interleukin-5 production leading to eosinophilia during late asthmatic response in guinea-pigs. Clinical and Experimental Allergy, 32: 633-640.

20. Baggiolini M, Walz A \& Kunkel SL (1989). Neutrophil-activating peptide-1/interleukin 8, a novel cytokine that activates neutrophils. Journal of Clinical Investigation, 84: 1045-1049. 